\title{
A NEW NORTHERN LIMIT FOR THE DISTRIBUTION OF RANUNCULUS SPEGAZZINII LOURTEIG (RANUNCULACEAE) IN CHILE
}

\author{
EXTENSION DEL RANGO DE DISTRIBUCION DE RANUNCULUS \\ SPEGAZZINII LOURTEIG (RANUNCULACEAE) EN CHILE
}

\author{
Carlos A. Lehnebach ${ }^{1}$, Magaly Rivero ${ }^{2}$, Cecilia Ezcurra ${ }^{3}$ \& Peter J. Lockhart ${ }^{1}$ \\ ${ }^{1}$ Allan Wilson Centre, Massey University. Private Bag 11222. Palmerston North. New Zealand. \\ ${ }^{2}$ Instituto de Botánica, Universidad Austral de Chile. Casilla 567. Valdivia. Chile \\ ${ }^{3}$ Centro Regional Universitario Bariloche. San Carlos de Bariloche. Argentina. \\ C.A.Lehnebach@massey.ac.nz / c_lehnebach@hotmail.com
}

\section{RESUMEN}

Se informa la colecta de Ranunculus spegazzinii Lourteig en la IX Región de Chile $\left(38^{\circ} \mathrm{S}\right)$. Este nuevo registro extiende el límite norte de distribución de esta especie en Chile en c. $1400 \mathrm{~km}$. Además se presenta un mapa con los puntos de colecta de $R$. spegazzinii e imágenes del nectario y aquenio obtenidas en el microscopio electrónico de barrido.

Ranunculus L. is the largest genus in the Ranunculaceae family. It comprises about 600 species (Tamura 1993, 1995) and its distribution is almost worldwide. In Chile, Ranunculus includes 22 native species (Ruiz 2001). They are usually found in moist habitats such as streams or lake banks, wetlands and forests; in lowland, sub-alpine and alpine environments. The distribution of this genus in Chile extends from the Altiplano in the northern Andes to the cold Patagonian streams and ponds in the South. It is in Patagonia where most of the Chilean Ranunculus species occur, many of them growing sympatrically.

Ranunculus spegazzinii Lourteig is one of the many native buttercups found in Patagonia. The species is characterized by the glabrous habit and large creeping stems. Leaves are homomorphous with ovate lamina, basally truncated and only slightly 3-5-lobed or crenate apex. Flowers are single, yellow, with calyx and corolla 5-6-merous and less than 10 finely foveolated carpels. The oblonglanceolate petals bear one nectary gland only, and this is located in the upper half of the petal. The nectary is small and pocket-like (Fig $1 \mathrm{~A}$ ), with the nectary scale tightly covering the nectary gland (Fig.
$1 \mathrm{~B})$. The achene testa is reticulated with irregular and not isodiametric cells (Fig. 1 C). Anticlinal cell walls are raised, straight or slightly curved and periclinal cell walls are concave and with no apparent ornamentation (Fig. 1 D). The latter characters confer the foveolate surface pattern observed in the achenes of this species.

In Chile, the distribution of $R$. spegazzinii is remarkably limited and it has been collected only in Torres del Paine National Park, XII Region (51 ${ }^{\circ} 03$ 'S) (Fig. 2, point 4). In Argentina, on the contrary, $R$. spegazzinii has a widespread distribution and it has been collected in the southern provinces of Neuquén, Río Negro and Chubut (Lourteig 1984, Zuloaga \& Morrone 1999) (Fig. 2, points 1, 2, 3). A recent expedition to the Cordillera de los Andes in the IX Region of Chile, part of a broader study on the phylogenetic affinities of Southern South American Ranunculus, has evidenced the occurrence of $R$. spegazzinii in this region. This collection extends the northern limit of distribution for this species in Chile in almost $1400 \mathrm{~km}$. This location, however, is relatively close to the northern limit of distribution previously recorded for this species in Argentina (Fig. 2, point 1). 

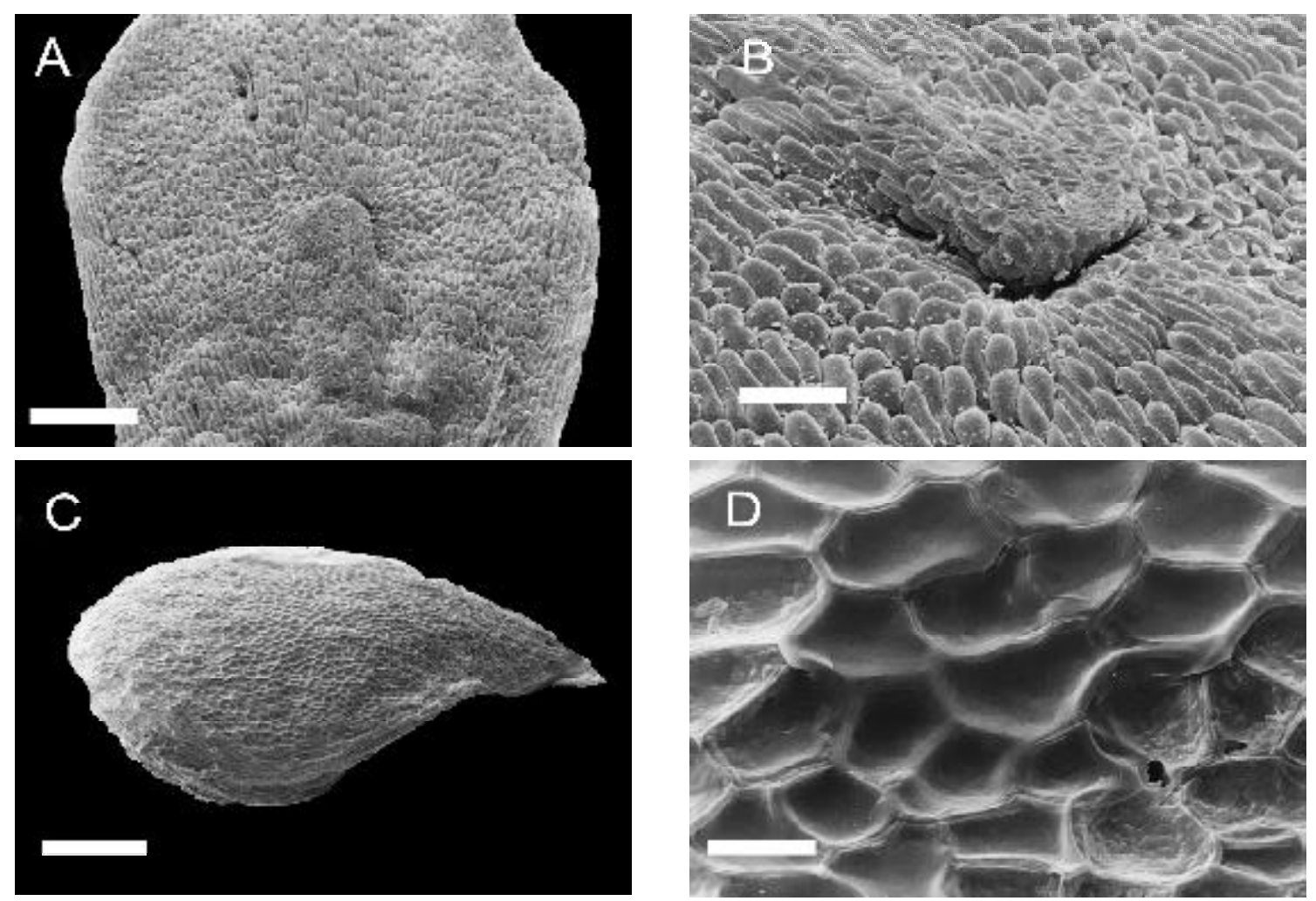

FigURE 1. SEM micrographs of Ranunculus spegazzinni petal with nectary (A), close up of nectary scale (B), achene (C) and achene surface (D). Scale bars: $A=100 \mu \mathrm{m} ; B=50 \mu \mathrm{m} ; C=500 \mu \mathrm{m} ; \mathrm{D}=20 \mu \mathrm{m})$. A and B from Lehnebach s.n. (MPN); C and D from Lehnebach \& Ezcurra s.n. (MPN).

FIGURA 1. Fotografía de microscopía electrónica de barrido del pétalo (A), nectario (B), aquenio (C) y superficie del aquenio (D) de Ranunculus spegazzinni. Escala: $A=100 \mu \mathrm{m} ; \mathrm{B}=50 \mu \mathrm{m} ; \mathrm{C}=500 \mu \mathrm{m} ; \mathrm{D}=20 \mu \mathrm{m}$ ). A y B de Lehnebach s.n. (MPN); C y D de Lehnebach \& Ezcurra s.n. (MPN).

\section{METHODS}

Species identification and determination of collection details were assisted by descriptions available from the literature (Lourteig 1951, 1984, Ruiz 2001) and the study of material from past collections found in the herbaria CONC and SI. Flowering and fruiting individuals of $R$. spegazzinii were collected and fixed in $50 \%$ ethanol. Later, petals were dehydrated using ethanol series of 50, 70, 85 and $100 \%$. After dehydration, petals were critical point dried and sputter-coated with gold and observed under the SEM (Cambridge 250). Achenes were etched with Driselase $1 \%$ for $24 \mathrm{~h}$ to expose cell microcharacters, rinsed with distilled water and then air dried. Achenes were sputter-coated with gold and observed under the SEM.
SPECIMENS STUdied

ARGENTINA: Neuquén. Dpto. Aluminé: brazo muerto de poca profundidad del arroyo Calfiquitra. SW lago Ruca Choroi. Parque Nacional Lanin. 02II-1968. Eskuche \& Klein 218 (SI). Rio Negro. Dpto. San Carlos de Bariloche: Llao-Llao. 12-III-2004 Lehnebach \& Ezcurra s.n. (MPN).

CHILE: IX Region. Provincia de Cautín, cuesta Fusta, close to Quimquén, pond by the road, 1160masl. 3840'S-71 ²2'W. 01-II-2006. Lehnebach s.n. (MPN). XII Region, Provincia de Ultima Esperanza, Parque Nacional Torres del Paine, Lago Skottsberg 500m W, 100 masl. 51 ${ }^{\circ} 03^{\prime}$ S7305'W. 11-III-1998. Elvebackk \& Bjerke 98:477 (CONC). 


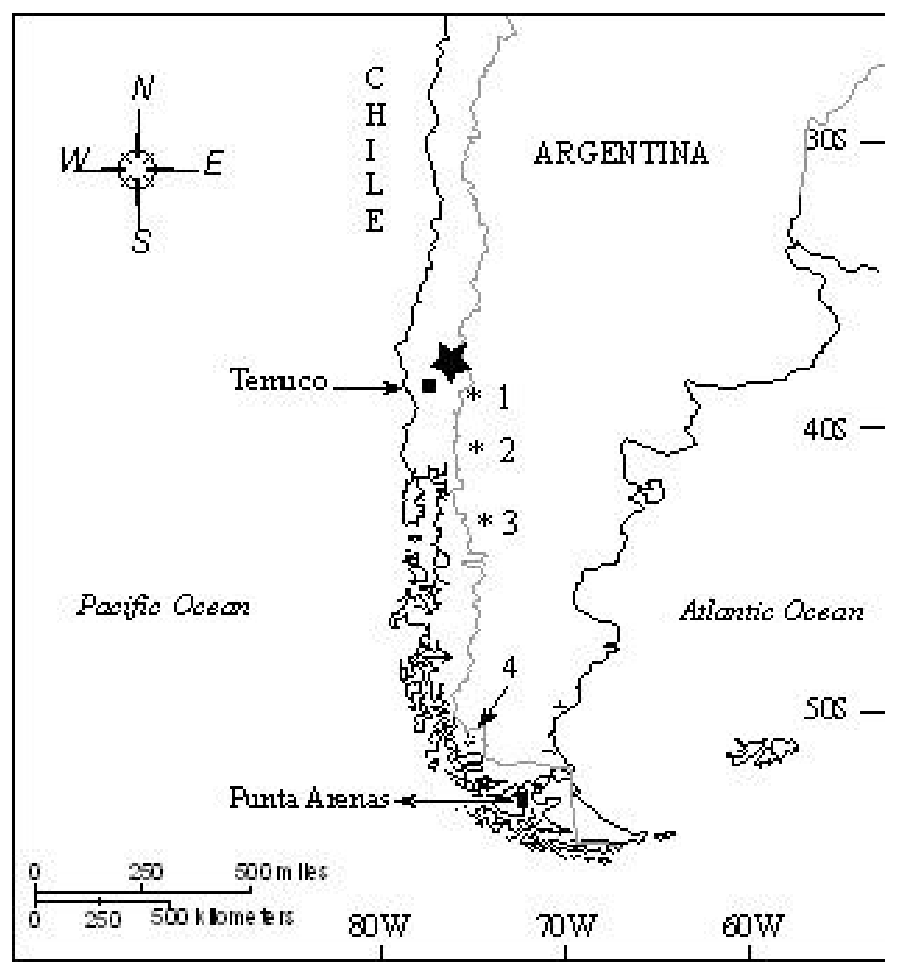

FIGURE 2. New collection of Ranunculus spegazzinii in the IX Region of Chile ( $\star$ ) and previous collections in Argentina and Chile (1: Neuquén, 2: Rio Negro, 3: Chubut, 4: Torres del Paine National Park).

Figura 2. Nueva colecta de Ranunculus spegazzinii en la IX Región de Chile ( $\star$ ) y previas colectas en Argentina y Chile (1: Neuquén, 2: Rio Negro, 3: Chubut, 4: Parque Nacional Torres del Paine).

\section{ACKNOWLEDGMENTS}

The authors want to thank Dr. N. Deginani (Instituto Darwinion) and Dr. R. Rodríguez (Universidad de Concepción) for allowing the study of the material deposited in the herbaria SI and CONC, Rosy Montero (CONC), and D. Hopcroft and R. Silva for help with the SEM. Funding for this study was provided by the New Zealand Postgraduate Study Abroad Award to CAL and the Allan Wilson Centre.

\section{REFERENCES}

Lourteig, A. 1951. Ranunculáceas de Sudamérica templada. Darwiniana 9(3-4): 445-608.
Lourteig, A. 1984. Ranunculaceae. En M.N. Correa (Ed.), Fl. Patagónica, Colección Científica Instituto Nacional Tecnología Agropecuaria 8(4a): 284-322.

Ruiz, E. 2001. Ranunculaceae. In C. Marticorena \& R. Rodríguez (Eds). Flora de Chile 2: 40-84.

Tamura, M. 1993. Ranunculaceae. En K. Kubitzki, J. G. Rowher \& V. Bittrich (Eds.), The families and genera of vascular plants. pp. 563-583. Springer-Verlag, Berlin.

Tamura, M. 1995. Systematic Part. In P. Hiepko (Ed.), Die Natürliche Pflanzenfamilien: Ranunculaceae. Duncker \& Humboldt, Berlin. pp. 223-519.

Zuloaga, F.O. \& O. Morrone. 1999. Ranunculaceae. In F. Zuloaga \& O. Morrone (Eds.). Catálogo de las Plantas Vasculares de la Argentina: Dicotyledoneae. Monographs in Systematic Botany from the Missouri Botanical Garden 74: 964-974. 